\title{
IMPACT OF DEFORESTATION ON CHANGES OF ION SHARE IN CHEMICAL COMPOSITION OF WATERS OF THE MALINOWSKI STREAM ALONG LONGITUDINAL HYDROCHEMICAL PROFILES
}

\author{
Amanda Kosmowska ${ }^{\bowtie}$ \\ Institute of Geography and Spatial Management, Jagiellonian University in Kraków, ul. Gronostajowa 7, 30-387 Kraków
}

\begin{abstract}
Aim of the study

The aim of the study was to determine the changes of ion share in chemical composition of water with the catchment area increase along longitudinal hydrochemical profiles in an area affected by an ecological disaster.

Material and methods

The research was conducted in the Malinowski stream catchment in the Skrzyczne massif in the Silesian Beskid mountain range from 2013 to 2014. The catchment was divided into smaller sub-catchments (dependent and independent) and 6 longitudinal profiles were separated along the catchment with the increase in the catchment area surface. Water samples were collected in catchments with a different deforestation level on a monthly basis and its physical and chemical features $\left(\mathrm{pH}, \mathrm{EC}_{25^{\circ} \mathrm{C}}\right.$, Tw) were measured. The chemical composition of water was determined with the ion chromatography method (DIONEX 2000) in the range of 14 ions $\left(\mathrm{Ca}^{2+}, \mathrm{Mg}^{2+}, \mathrm{Na}^{+}, \mathrm{K}^{+}, \mathrm{NH}_{4}^{+}, \mathrm{Li}^{+}, \mathrm{HCO}_{3}^{-}, \mathrm{SO}_{4}^{2-}, \mathrm{Cl}^{-}, \mathrm{NO}_{2}^{-}, \mathrm{NO}_{3}^{-}, \mathrm{PO}_{4}^{3-}, \mathrm{Br}^{-}, \mathrm{F}^{-}\right)$.
\end{abstract}

\section{Results and conclusions}

The conducted research showed the impact of deforestation on the ion share in the chemical composition of water. In the deforested catchments, an increase in the share of $\mathrm{SO}_{4}^{2-}$, and a decrease in the share of $\mathrm{HCO}_{3}^{-}$ were observed. The share of $\mathrm{SO}_{4}^{2-}$ in the waters that were draining the deforested catchment was so high that it occured in the first position in the water's hydrochemical type, while the concentration of $\mathrm{HCO}_{3}^{-}$was so low that its share was minimal. The analysis of hydrochemical types changes along longitudinal profiles showed the difference in chemical composition of waters draining the upper, deforested zone in comparison to the lower, forested zone. As the catchment area increases, the importance of $\mathrm{NO}_{3}^{-}$decreases and the importance of $\mathrm{HCO}_{3}^{-}$increases. If the research was conducted exclusively in the profile that closes the Malinowski stream catchment it would show that the catchment is a typical Carpathian catchment in hydrochemical terms, where bicarbonates are in the first place in water chemical composition. The analysis of water chemical composition conducted in the longitudinal profiles enables the identification of hydrochemical effects of the degradation of forest stand in mountain catchment.

Keywords: stream water chemistry, deforestation, acidic atmospheric deposition, concentration of $\mathrm{NO}_{3}^{-}$and $\mathrm{SO}_{4}^{2-}$ 


\section{INTRODUCTION}

The chemical composition of stream waters in catchment according to Macioszczyk (1987), Pazdro and Kozerski (1990), Chełmicki (2012) is determined by an array of environmental factors. National factors such as geological structure, susceptibility to weathering and leaching, total precipitation play a dominant role. Also, it is strongly influenced by vegetation and plant root systems that, on one hand, collect water from the system, and on the other, change physicochemical conditions of the soil layer (or ground and residual soil layers), and promote the passage of chemical ingredients into soil solution. Even minor surface changes in terms of land use conditions (e.g. deforestation) in seepage spring area can strongly influence water's chemical composition (Czop et al., 2008). Today, in the period of a growing anthropopressure, human economic activity plays increasingly important role (Chełmicki, 2012). Atmospheric pollution has a negative impact on forest ecosystems as it is a direct cause of acid rainfalls (Bytnerowicz et al., 2002; Małek et al., 2005), it disturbs the natural chemistry of precipitation, surface and underground waters as well as soil (Małek and Gawęda, 2006a, 2006b; Małek, 2010; Borg and Sundbom, 2014). In the Silesian Beskid range it was shown that strong anthropopressure led to dying of forest stand in mountain areas (Małek and Krakowian, 2012; Kosmowska et al., 2016), and aggradation of sulphur and nitrogen compounds may cause disturbances in proper functioning of water and land ecosystems (Moldan and Schnoor, 1992; Borg and Sundbom, 2014).

The aim of the study was to determine the changes of ion share in chemical composition of water with the catchment area increase along longitudinal hydrochemical profiles in an area affected by an ecological disaster of dying of spruce.

\section{RESEARCH SITE}

The research on changes in a chemical composition of waters was conducted in the Malinowski stream catchment. The catchment is located in the Skrzyczne massif, the highest peak (1257 m a.s.l.) in the Silesian Beskid range. It is designated by the side ridge of the Skrzyczne massif, which stretches southwest through
Małe Skrzyczne (1211 m a.s.l.), Kopa Skrzyczańska (1189 m a.s.1.) up to Malinowska Skała (1152 m a.s.l.) (see: Fig. 1). In terms of physical and geographical regionalisation, the area belongs to the Western Carpathians province, the Outer Carpathians sub-province, the Western Beskid macroregion and the Silesian Beskid mesoregion (Balon and Jodłowski, 2014).

These mountains were uplifted during the Alpine orogeny in the late Paleogene and the Miocene (Oszczypko, 1995). The glaciation that occurred in the Quaternary had a great impact on the relief of the area. As a result of intensive periglacial processes, characteristic gentle slopes and peaks formed that are intersected by deep valleys. The current landform of the Silesian Beskid is formed mainly as a result of water erosion. Landslides on slopes and valleys, which are the result of undercutting slopes by water erosion, play a major role in the evolution of the landform (Małek and Gawęda, 2004). Mountain ranges of the Silesian Beskid are formed of the Godula sandstone with a low content slates (Alexandrowicz, 1999; Geologiczna Mapa Polski 1:50000 1966a, 1966b).

This area is covered with a forest stand characterised by a high share of the Istebna spruce that grows mainly in monocultures (Barszcz and Małek, 2015). This spruce, however, is not a native species in the Silesian Beskid, hence its share in natural forest stands was low in the past. In the 18th century, along with the increase in the development of industry and agriculture, robbery of wood resources (beech and sycamore) increased. Natural lower subalpine forests were destroyed and replaced with monocultures of spruce of foreign origin, which with time began to disintegrate (Małek, 2015). The main reason for the dying out of forest stands in the research site was the bad condition of forest caused by the immission of industrial pollution from the Czech Republic and the Silesian-Cracow agglomeration. The dying out concerned mainly forests located in the ridge parts of the highest hills, most exposed to weather conditions (Capecki, 1994; Kosmowska et al., 2016; Małek et al., 2012a, 2012b).

The Malinowski stream catchment is limited by a stream gauge of the Polish Institute of Meteorology and Water Management (IMGW) in Lipowa, and it was monitored by the IMGW until 1983. In the 1974 to 1983 hydrological decade, the average discharge of the 
Malinowski stream was $0.64 \mathrm{~m}^{3} \cdot \mathrm{s}^{-1}$ and ranged from $Q_{\min }=0.04 \mathrm{~m}^{3} \cdot \mathrm{s}^{-1} 11.11 .1983 \mathrm{r}$. to $Q_{\max }=12.4 \mathrm{~m}^{3} \cdot \mathrm{s}^{-1}$ 20.01.1974 r. (Hydrologiczny rocznik wód powierzchniowych, 1974-1983). Average annual rainfall in the Silesian Beskid is $1400 \mathrm{~mm}$ and average annual air temperature in the lower subalpine forest is $5.6^{\circ} \mathrm{C}$. The average duration of the growing season is 192 days (Durło, 2012).

The Malinowski stream catchment has an area of $21.39 \mathrm{~km}^{2}$. Sub-catchments located in the upper, ridge forest zone are independent and are characterised by a small area not exceeding $0.1 \mathrm{~km}^{2}$. These catchments

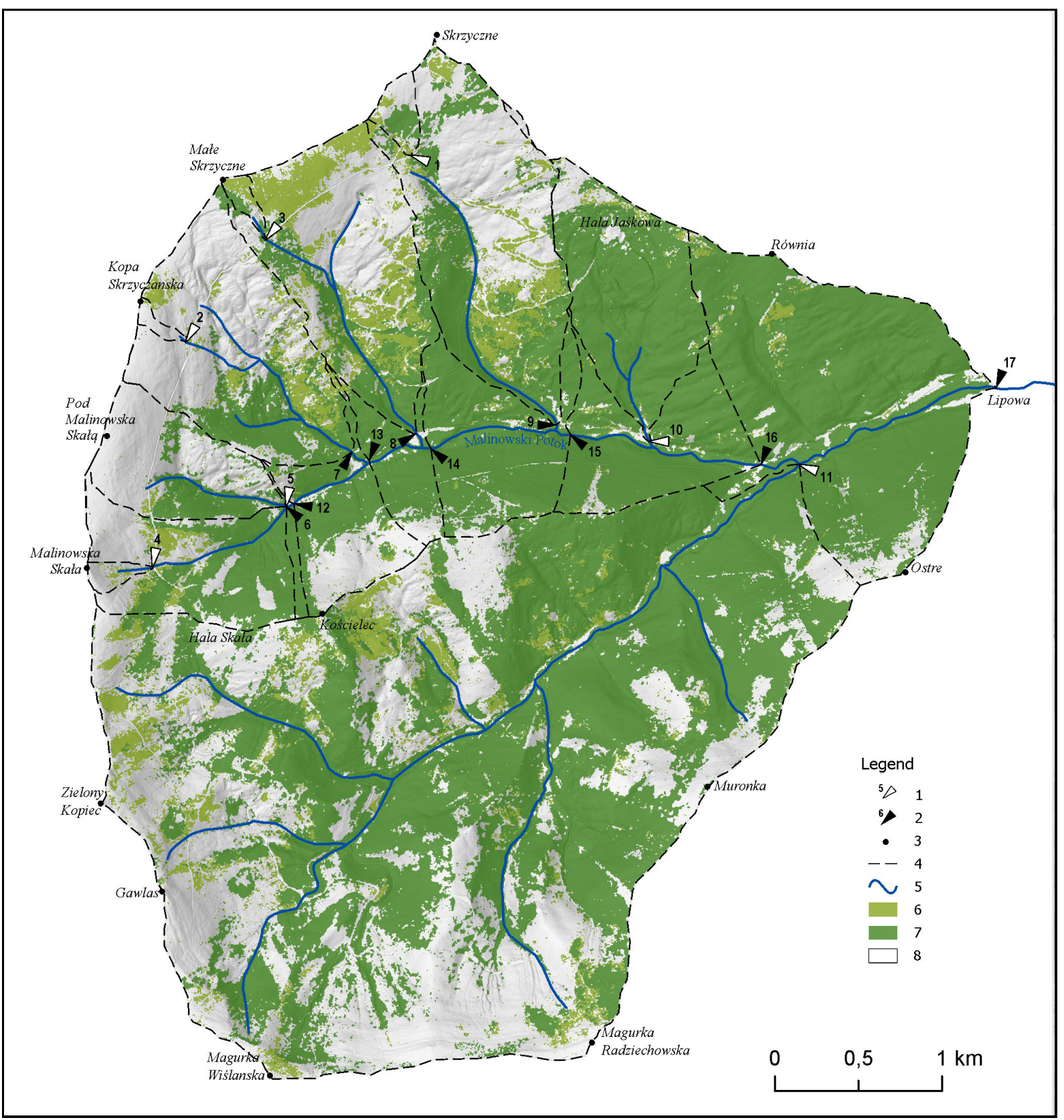

Fig. 1. Study area - Malinowski stream catchment 1 - independent catchments closing profiles, 2 - dependent catchments closing profiles, 3 - peaks, 4 - catchment boundaries, 5 - streams, 6 - young forest, 7 - high forest, 8 - deforested area 
are the most deforested, from $1.3 \%$ of the forest cover in catchment no. 2 to $52.0 \%$ in catchment no. 1 . Catchment no. 4 is deforested in $85.3 \%$ and is currently covered by young forest. Catchments (dependent and independent) located in the middle forest zone are characterised by a larger area ranging from $0.34 \mathrm{~km}^{2}$ to $1.62 \mathrm{~km}^{2}$ and much greater afforestation ranging from $44.2 \%$ to $85.9 \%$. Catchments located in the lower forest zone are mostly dependent and they limit hydrochemical systems. They cover area ranging from $1.63 \mathrm{~km}^{2}$ to $21.9 \mathrm{~km}^{2}$, and their ranges from $57.1 \%$ to $69.9 \%$ (see: Table 1).

Table 1. Characteristics of sub-catchments of the Malinowski stream

\begin{tabular}{|c|c|c|c|c|c|c|c|}
\hline \multirow{3}{*}{ Forest zones } & \multirow{3}{*}{ ID } & \multirow{3}{*}{$\begin{array}{c}\text { Type of } \\
\text { catchment }\end{array}$} & \multirow{2}{*}{ Area } & \multicolumn{3}{|c|}{ Forest cover } & \multirow{2}{*}{ Average slope } \\
\hline & & & & Young forest & High forest & Total & \\
\hline & & & {$\left[\mathrm{km}^{2}\right]$} & {$[\%]$} & {$[\%]$} & {$[\%]$} & {$\left[{ }^{\circ}\right]$} \\
\hline \multirow{4}{*}{ Upper } & 1 & I & 0.09 & 13.9 & 38.1 & 52.0 & 15.9 \\
\hline & 2 & I & 0.03 & 1.2 & 0.1 & 1.3 & 15.4 \\
\hline & 3 & I & 0.04 & 27.1 & 22.9 & 50.0 & 12.9 \\
\hline & 4 & I & 0.05 & 12.8 & 1.9 & 14.7 & 24.2 \\
\hline \multirow{6}{*}{ Middle } & 5 & I & 0.34 & 3.7 & 40.5 & 44.2 & 9.9 \\
\hline & 6 & $\mathrm{D}$ & 1.00 & 7.1 & 41.0 & 48.1 & 7.6 \\
\hline & 7 & $\mathrm{D}$ & 1.39 & 22.5 & 47.1 & 69.6 & 9.2 \\
\hline & 8 & $\mathrm{D}$ & 1.13 & 37.8 & 32.8 & 70.6 & 7.8 \\
\hline & 9 & $\mathrm{D}$ & 1.62 & 19.2 & 48.3 & 67.5 & 8.2 \\
\hline & 10 & I & 1.00 & 2.1 & 83.8 & 85.9 & 7.3 \\
\hline \multirow{6}{*}{ Lower } & 11 & I & 10.60 & 7.1 & 50.0 & 57.1 & 21.0 \\
\hline & 12 & $\mathrm{D}$ & 1.63 & 8.5 & 61.4 & 69.9 & 20.7 \\
\hline & 13 & $\mathrm{D}$ & 3.31 & 11.1 & 49.9 & 61.0 & 20.5 \\
\hline & 14 & $\mathrm{D}$ & 4.79 & 16.8 & 44.2 & 61.0 & 19.7 \\
\hline & 15 & $\mathrm{D}$ & 7.12 & 15.3 & 49.5 & 64.8 & 19.9 \\
\hline & 16 & $\mathrm{D}$ & 8.36 & 12.2 & 56.3 & 68.5 & 18.6 \\
\hline Malinowski Potok & 17 & $\mathrm{D}$ & 21.39 & 8.2 & 54.6 & 62.8 & 15.1 \\
\hline
\end{tabular}

Data source: own research - completed table (Kosmowska et at. 2016).

\section{RESEARCH METHODS: FIELD, LABORATORY AND DATA ANALYSIS}

\section{Field methods}

In order to determine the impact of deforestation on changes of ion share in chemical composition of waters in the Malinowski stream catchment, research was conducted from November 2013 to October 2014. The research was conducted in 17 sub-catchments of the Malinowski stream. In 7 independent catchments (I) (spring or divergent ones) and 10 dependent (D) (catchments partially covering areas of other catch- ments) (Ozga-Zielińska and Brzeziński, 1994). In each catchment, the physical and chemical properties of the water were measured monthly with the Professional YSI PLUS multi-parameter meter (YSI Inc., USA): water temperature, conductivity $\left(\mathrm{EC}_{25^{\circ} \mathrm{C}}\right)$ and $\mathrm{pH}$, and a water sample was taken to determine the chemical composition $(\mathrm{n}=204)$.

\section{Laboratory methods}

Physical properties and chemical composition of water were analysed in the Hydrological and Chemical Laboratory of the Institute of Geography and Spatial Man- 
agement of the Jagiellonian University (IGiGP UJ). In order to verify the values of $\mathrm{EC}$ and $\mathrm{pH}$ obtained with YSI meter in the field, they were analysed again in the laboratory. Subsequently, water samples were filtered through a syringe filter with a PTFE membrane $(0.45 \mu \mathrm{m})$ to prepare them for the chromatography analysis. Chemical composition analysis of water samples was conducted with the ion chromatography method with the DIONEX ICS 2000 system (Dionex Corporation, USA). 14 ions were determined in the range of:

1) main ions of: calcium $\left(\mathrm{Ca}^{2+}\right)$, magnesium $\left(\mathrm{Mg}^{2+}\right)$, sodium $\left(\mathrm{Na}^{+}\right)$, potassium $\left(\mathrm{K}^{+}\right)$, bicarbonate ions $\left(\mathrm{HCO}_{3}^{-}\right)$, sulphate $(\mathrm{VI})\left(\mathrm{SO}_{4}^{2-}\right)$, chloride $\left(\mathrm{Cl}^{-}\right)$;

2) biogenic compounds of: ammonium ions $\left(\mathrm{NH}_{4}^{+}\right)$, nitrate (III) $\left(\mathrm{NO}_{2}^{-}\right)$, nitrate $(\mathrm{V})\left(\mathrm{NO}_{3}^{-}\right)$, orthophosphate $(\mathrm{V})\left(\mathrm{PO}_{4}^{3-}\right)$

3) microelements of: lithium ions $\left(\mathrm{Li}^{+}\right)$, bromide $\left(\mathrm{Br}^{-}\right)$, fluoride $\left(\mathrm{F}^{-}\right)$.

The correctness of chemical analyses was verified based on the analysis of certified reference materials (Trios-94 [batch number 306]) and with the ion balance method (PN-89/C-04638/02). A detailed description of the progress of the laboratory procedure and methodology is presented in the monograph by Żelazny (Czasowo-przestrzenna zmienność cech fizykochemicznych wód Tatrzańskiego Parku Narodowego, 2012).

For interpretation, the main ions and $\mathrm{NO}_{3}^{-}$were selected, and other ions $\left(\mathrm{Li}^{+}, \mathrm{NH}_{4}^{+}, \mathrm{Br}^{-}, \mathrm{PO}_{4}^{3--}, \mathrm{NO}_{2}^{-}, \mathrm{F}^{-}\right)$ were ignored in table comparisons due to their low concentration (often below detection limit) (see: Table 2).

Table 2. Ion detection limits [LOD]

\begin{tabular}{|c|c|c|c|}
\hline \multirow{2}{*}{ Cation } & LOD & \multirow{2}{*}{ Anion } & LOD \\
\hline & {$\left[\mathrm{mg} \cdot \mathrm{dm}^{-3}\right]$} & & {$\left[\mathrm{mg} \cdot \mathrm{dm}^{-3}\right]$} \\
\hline $\mathrm{Ca}^{2+}$ & 0.005 & $\mathrm{HCO}_{3}^{-}$ & 0.025 \\
\hline $\mathrm{Mg}^{2+}$ & 0.005 & $\mathrm{SO}_{4}^{2-}$ & 0.01 \\
\hline $\mathrm{Na}^{+}$ & 0.01 & $\mathrm{NO}_{3}^{-}$ & 0.0025 \\
\hline $\mathrm{K}^{+}$ & 0.005 & $\mathrm{NO}_{2}^{-}$ & 0.0025 \\
\hline $\mathrm{NH}_{4}^{+}$ & 0.005 & $\mathrm{Cl}^{-}$ & 0.0025 \\
\hline \multirow[t]{3}{*}{$\mathrm{Li}^{+}$} & 0.005 & $\mathrm{~F}^{-}$ & 0.001 \\
\hline & & $\mathrm{Br}^{-}$ & 0.005 \\
\hline & & $\mathrm{PO}_{4}^{3-}$ & 0.01 \\
\hline
\end{tabular}

\section{Data analysis}

In order to determine the impact of deforestation on changes of ion share in chemical composition of water along longitudinal hydrochemical profiles:

- 6 longitudinal profiles (I, II, III, IV, V, VI) were designated along the catchment area (1-17) with the area increase. Profile I: $1-9-16-15-17$, profile II: 2-7-13-14-15-16-17, profile III: 3-8-14-15-16-17 , profile IV: 4-6-12-13-14-15-16-17, profile V: 5-12-13-14-15-16-17, profile VI: 10-16-17;

- for each sub-catchment, the degree of forest coverage, including young forest, and deforestation were calculated on the basis of aerial photographs taken in 2014;

- the average slope and catchment area were calculated for each sub-catchment;

- the chemical composition of waters was interpreted due to the share of ions in the chemical composition of water, expressed in $\left(\% \mathrm{mval} \cdot \mathrm{dm}^{-3}\right)$. The share of ions was calculated assuming that the marked cations and anions constitute $100 \%$ of the chemical composition of water. It was assumed that anions and cations constitute $50 \% \mathrm{mval} \cdot \mathrm{dm}^{-3}$ each so the total of anions $=$ the total of cations. For the above assumption to be met, the spread of balance error was used (Ratajczak and Witczak, 1983 after: Witczak et al., 2013). The general mineralisation of waters was assumed as the total of determined ions;

- in order to present the synthetic chemical composition of waters the commonly used in hydrochemistry Szczukariew-Prikłoński classification was used (after: Macioszczyk, 1987). It assumes that the chemical features of natural waters are decided by 6 main ions $\left(\mathrm{HCO}_{3}^{-}, \mathrm{SO}_{4}^{2-}, \mathrm{Cl}^{-}, \mathrm{Ca}^{2+}, \mathrm{Mg}^{2+}, \mathrm{Na}^{+}\right)$ share of which is not lower than $10 \% \mathrm{mval} \cdot \mathrm{dm}^{-3}$, and the name of a type starts with an anionic part in order from largest to smallest share. Due to the fact that the share of $\mathrm{NO}_{3}^{-}$in chemical composition of water sometimes exceeded $10 \% \mathrm{mval} \cdot \mathrm{dm}^{-3}$, $\mathrm{NO}_{3}^{-}$was included in the classification and it was written in the short name of the hydrochemical type in square brackets;

- the share of ions in the chemical compositions was expressed with hydrochemical types;

the seasonal change of chemical composition of waters was defined based on two criteria: 
- time and volume of the share of $\mathrm{NO}_{3}^{-}$in the structure of the chemical composition, expressed by the graph of the monthly coefficient of variation of the share of $\mathrm{NO}_{3}^{-}$in the structure of the chemical composition of water. It is the quotient of the monthly concentration of $\mathrm{NO}_{3}^{-}$ $\left(\% \mathrm{mval} \cdot \mathrm{dm}^{-3}\right)$ to the average annual concentration $\left(\mathrm{C}_{\text {month }} / \mathrm{C}_{\text {annual avg. }}\right)$,

- the variability of the $\mathrm{NO}_{3}^{-}$share marked with the coefficient of variation $(\mathrm{Cv})$ that expresses the ratio of the standard deviation to the average, expressed as a percentage. The following criterion was adopted: $\mathrm{Cv}<10 \%$ - equalised type, $10<\mathrm{Cv}<20$ - moderate type, $\mathrm{Cv}>20-$ non-equalised type;

- the chemical composition of stream waters was characterised with the following statistical measures: arithmetic mean, minimum and maximum value.

\section{RESULTS OF THE STUDY}

\section{General characteristics}

Water courses draining the forested catchments of the Malinowski stream are characterised by a weakly alkaline reaction, while the water courses draining catchments located higher, closer to ridges, and that are more deforested, are characterised by higher acidification (lower $\mathrm{pH}$ ) and belong to medium acid waters [according to the division Pazdro and Kozerski (1990)]. In terms of mineralisation, these waters are low-mineralised and belong to so-called ultra-fresh waters (see: Table 3). Chemical composition analysis of waters draining forested and deforested catchments, show particularly large diversity within anions. $\mathrm{SO}_{4}^{2-}$ share in the chemical composition of waters draining independent, deforested catchments in the upper, ridge zone of the Skrzyczne massif is very large and that is

Table 3. Values of $\mathrm{pH}$, electrical conductivity $\left(\mathrm{EC}_{25^{\circ} \mathrm{C}}\right)$, mineral content $\left(\mathrm{M}_{\mathrm{t}}\right)$ and coefficient of variation $(\mathrm{Cv})$ in stream water $(\mathrm{n}=12)$

\begin{tabular}{|c|c|c|c|c|c|c|c|c|c|c|c|c|c|}
\hline \multirow{3}{*}{ Forest zones } & \multirow{3}{*}{ ID } & \multicolumn{4}{|c|}{$\mathrm{pH}$} & \multicolumn{4}{|c|}{$\mathrm{EC}_{25^{\circ} \mathrm{C}}$} & \multicolumn{4}{|c|}{$\mathrm{M}_{\mathrm{t}}$} \\
\hline & & Min. & Avg. & Max. & $\mathrm{Cv}$ & Min. & Avg. & Max. & $\mathrm{Cv}$ & Min. & Avg. & Max. & $\mathrm{Cv}$ \\
\hline & & \multicolumn{3}{|c|}{$(\mathrm{pH})$} & {$[\%]$} & \multicolumn{3}{|c|}{$\left[\mu \mathrm{S} \cdot \mathrm{cm}^{-1}\right]$} & {$[\%]$} & \multicolumn{3}{|c|}{$\left[\mathrm{mg} \cdot \mathrm{dm}^{-3}\right]$} & {$[\%]$} \\
\hline \multirow{4}{*}{ Upper } & 1 & 6.33 & 6.49 & 6.57 & 1.0 & 43.8 & 47.3 & 51.1 & 5.1 & 27.67 & 31.45 & 35.25 & 6.8 \\
\hline & 2 & 5.71 & 5.81 & 5.98 & 1.5 & 38.3 & 40.0 & 41.8 & 3.0 & 21.86 & 23.91 & 25.83 & 5.7 \\
\hline & 3 & 6.28 & 6.45 & 6.55 & 1.5 & 44.2 & 49.3 & 52.8 & 5.1 & 29.38 & 35.16 & 41.04 & 9.7 \\
\hline & 4 & 7.04 & 7.14 & 7.37 & 1.4 & 59.2 & 74.3 & 82.8 & 8.6 & 46.93 & 53.69 & 58.04 & 6.1 \\
\hline \multicolumn{2}{|l|}{ Average value } & 6.34 & 6.47 & 6.62 & 1.4 & 46.4 & 52.7 & 57.1 & 5.5 & 31.46 & 36.05 & 40.04 & 7.1 \\
\hline \multirow{6}{*}{ Middle } & 5 & 7.14 & 7.37 & 7.59 & 1.7 & 73.1 & 83.6 & 91.8 & 7.3 & 56.29 & 61.22 & 67.65 & 6.3 \\
\hline & 6 & 7.05 & 7.25 & 7.38 & 1.2 & 62.1 & 74.2 & 91.2 & 10.3 & 47.21 & 53.92 & 65.85 & 9.4 \\
\hline & 7 & 7.28 & 7.38 & 7.54 & 0.9 & 74.2 & 83.5 & 88.8 & 5.2 & 56.13 & 61.29 & 68.00 & 7.0 \\
\hline & 8 & 7.09 & 7.23 & 7.33 & 1.0 & 59.0 & 64.8 & 71.5 & 5.2 & 42.75 & 47.06 & 56.72 & 8.4 \\
\hline & 9 & 7.09 & 7.22 & 7.34 & 1.1 & 65.5 & 73.1 & 78.0 & 5.4 & 46.41 & 52.22 & 57.50 & 6.7 \\
\hline & 10 & 7.15 & 7.32 & 7.56 & 1.6 & 59.3 & 69.8 & 81.2 & 9.5 & 39.95 & 51.44 & 61.99 & 11.9 \\
\hline \multicolumn{2}{|l|}{ Average value } & 7.13 & 7.30 & 7.46 & 1.3 & 65.5 & 74.8 & 83.8 & 7.2 & 48.12 & 54.53 & 62.95 & 8.3 \\
\hline \multirow{6}{*}{ Lower } & 11 & 7.06 & 7.37 & 7.56 & 1.9 & 64.6 & 76.2 & 82.2 & 6.3 & 51.78 & 56.75 & 65.41 & 7.4 \\
\hline & 12 & 7.17 & 7.26 & 7.36 & 0.9 & 66.3 & 78.1 & 85.3 & 7.2 & 50.20 & 57.41 & 64.03 & 6.9 \\
\hline & 13 & 6.89 & 7.30 & 7.49 & 2.3 & 48.4 & 77.2 & 85.3 & 15.0 & 40.98 & 56.86 & 65.66 & 13.3 \\
\hline & 14 & 6.93 & 7.26 & 7.52 & 2.4 & 47.6 & 74.5 & 93.4 & 14.7 & 41.76 & 55.06 & 63.03 & 11.4 \\
\hline & 15 & 6.65 & 7.25 & 7.49 & 3.2 & 41.4 & 73.8 & 90.0 & 15.9 & 34.34 & 53.27 & 60.00 & 12.9 \\
\hline & 16 & 7.11 & 7.31 & 7.54 & 1.6 & 66.9 & 76.2 & 88.3 & 7.5 & 49.77 & 55.11 & 61.06 & 7.0 \\
\hline Malinowski stream & 17 & 7.18 & 7.35 & 7.55 & 1.3 & 67.0 & 76.5 & 81.5 & 6.0 & 50.62 & 56.19 & 62.99 & 7.3 \\
\hline \multicolumn{2}{|l|}{ Average value } & 7.00 & 7.30 & 7.50 & 1.9 & 57.5 & 76.1 & 86.6 & 10.4 & 45.64 & 55.81 & 63.17 & 9.5 \\
\hline \multicolumn{2}{|l|}{ Average total } & 6.89 & 7.10 & 7.28 & 1.6 & 57.7 & 70.1 & 78.7 & 8.1 & 43.18 & 50.71 & 57.65 & 8.5 \\
\hline
\end{tabular}


$20.72 \% \mathrm{mval} \cdot \mathrm{dm}^{-3}$ on average, and in catchment no. 2 (almost totally deforested) is up to $31.58 \% \mathrm{mval} \cdot \mathrm{dm}^{-3}$, while in forested catchments in the middle and lower zone of the Skrzyczne massif it is much lower (avg. = $14.30 \% \mathrm{mval} \cdot \mathrm{dm}^{-3}$ and avg. $\left.=14.38 \% \mathrm{mval} \cdot \mathrm{dm}^{-3}\right)$. Average share of $\mathrm{NO}_{3}^{-}$in waters from ridge zone is twice as high (avg. $=10.19 \% \mathrm{mval} \cdot \mathrm{dm}^{-3}$ ) as in forested catchments in the middle and lower zones (avg. $=5.42 \% \mathrm{mval} \cdot \mathrm{dm}^{-3}$ and avg. $=4.62 \% \mathrm{mval} \cdot \mathrm{dm}^{-3}$ ). However, the average share of $\mathrm{HCO}_{3}^{-}$in the chemical composition of waters is almost twice as high in forested catchments (avg. $=28.32 \% \mathrm{mval} \cdot \mathrm{dm}^{-3}$ and avg. $\left.=29.20 \% \mathrm{mval} \cdot \mathrm{dm}^{-3}\right)$ than in deforested catchments $\left(\right.$ avg. $\left.=16.59 \% \mathrm{mval} \cdot \mathrm{dm}^{-3}\right)($ see: Table 4$)$.

\section{Hydrochemical types}

In terms of hydrochemistry, three-ion waters dominate in each of dependent and independent catchments, and they are described with the $\mathrm{HCO}_{3}-\mathrm{SO}_{4}-\mathrm{Ca}$ type $(\mathrm{n}=166 ; 81 \%)$. In the ridge zone, the hydrochemical types of waters are more varied $(n=48)$. Four-ion waters of the $\mathrm{HCO}_{3}-\mathrm{SO}_{4}-\left[\mathrm{NO}_{3}\right]-\mathrm{Ca}$ type dominate $(\mathrm{n}=23 ; 48 \%)$, next are three-ion waters of the $\mathrm{HCO}_{3}-$ $\mathrm{SO}_{4}-\mathrm{Ca}$ type $(\mathrm{n}=13 ; 27 \%)$ and some waters of the following types: $\mathrm{SO}_{4}-\left[\mathrm{NO}_{3}\right]-\mathrm{Ca}-\mathrm{Mg}(\mathrm{n}=6 ; 13 \%)$, $\mathrm{SO}_{4}-\mathrm{Ca}-\mathrm{Mg}(\mathrm{n}=3 ; 6 \%), \mathrm{SO}_{4}-\left[\mathrm{NO}_{3}\right]-\mathrm{Ca}(\mathrm{n}=1 ; 2 \%)$, and two-ion waters of the $\mathrm{SO}_{4}-\mathrm{Ca}$ type $(\mathrm{n}=2 ; 4 \%)$. In the middle and lower catchment, waters of the $\mathrm{HCO}_{3}-$ $\mathrm{SO}_{4}-\mathrm{Ca}$ type dominate $(\mathrm{n}=153 ; 98 \%)$. The $\mathrm{HCO}_{3}-$ $\mathrm{SO}_{4}-\left[\mathrm{NO}_{3}\right]-\mathrm{Ca}$ type $(\mathrm{n}=1 ; 0,6 \%)$ was observed only once in the middle zone, and in the lower the $\mathrm{HCO}_{3}-$ Ca type $(\mathrm{n}=2 ; 1,4 \%)$ was observed twice (see: Table 5). The occurrence of this different hydrochemical type of water in the lower zone is probably related to the rapid, one-hour rainfall that occurred during the field research and water sampling.

\section{Longitudinal profiles}

Analysis of changes in the share of ions in the chemical composition of water shows that along the longitudinal hydrochemical profiles two different phenomena can be observed: enrichment and depletion of water into single ions, which results in an increase or decrease in the share of some ions expressed in $\% \mathrm{mval} \cdot \mathrm{dm}^{-3}$ in the chemical composition of water in sub-catchments of the Malinowski stream. In the case of $\mathrm{NO}_{3}^{-}$, a decrease of their share in the chemical composition of water usually occurs, in the direction away from ridge catchments toward stream mouths (profiles: I, II, IV, V). $\mathrm{HCO}_{3}^{-}$act differently as with an increase of catchment area, their share in chemical composition of water increases (profile II). $\mathrm{SO}_{4}^{2-}$ act irregularly as both their increase and decrease in the chemical composition of water can be observed (see: Fig. 2).

\section{Seasonal changes in the structure of the chemical composition of waters}

Analysis of seasonal changes in the share of ions in the chemical composition of water shows no changes expressed in hydrochemical types of water for most catchments $(n=12)$. In four catchments, one change of hydrochemical type of water was observed in a year and several changes in catchment no. 2 - the most deforested one. In catchment no. 2, chemical composition of water is more complex in winter and spring - four-ion waters $\mathrm{SO}_{4}-\left[\mathrm{NO}_{3}\right]-\mathrm{Ca}-\mathrm{Mg}$, while in summer and autumn more diverse hydrochemical types of water can be observed: two-ion waters $\mathrm{SO}_{4}-\mathrm{Ca}$ and three-ion waters: $\mathrm{SO}_{4}-\left[\mathrm{NO}_{3}\right]-\mathrm{Ca}, \mathrm{SO}_{4}-\mathrm{Ca}-\mathrm{Mg}$ (see: Table 5).

Analysing changes in the share of $\mathrm{NO}_{3}^{-}$in the chemical composition of water during the year, the changes observed were in line with expectations and opposite to expected. In most catchments $(1,2,5,6,7,8,12,13$, $14,17)$, a bigger share of $\mathrm{NO}_{3}^{-}$in the chemical composition of water was observed in winter, while a smaller one in summer (see: Fig. 3). It is associated with the accumulation of nitrogen by plants during the growing season. At the time, the concentration of $\mathrm{NO}_{3}^{-}$in waters decreases and their share in the chemical composition of water also decreases. A different phenomenon was observed in some heavily forested catchments $(3,9$, 10 ) - in summer there was more $\mathrm{NO}_{3}^{-}$in the chemical composition of water, while in winter there was less (see: Fig. 3). This may indicate a continuous breakdown of the forest stand in the catchment of the Malinowski stream. In some catchments $(4,11,15,16)$, no clearly oriented changes can be observed.

Analysing the variability of $\mathrm{NO}_{3}^{-}$expressed with the variability coefficient, it was observed that it is mostly moderate (in nine catchments). The remaining, extreme types - equalised and non-equalised - occur each of four. Diversity of types shows that the forest 


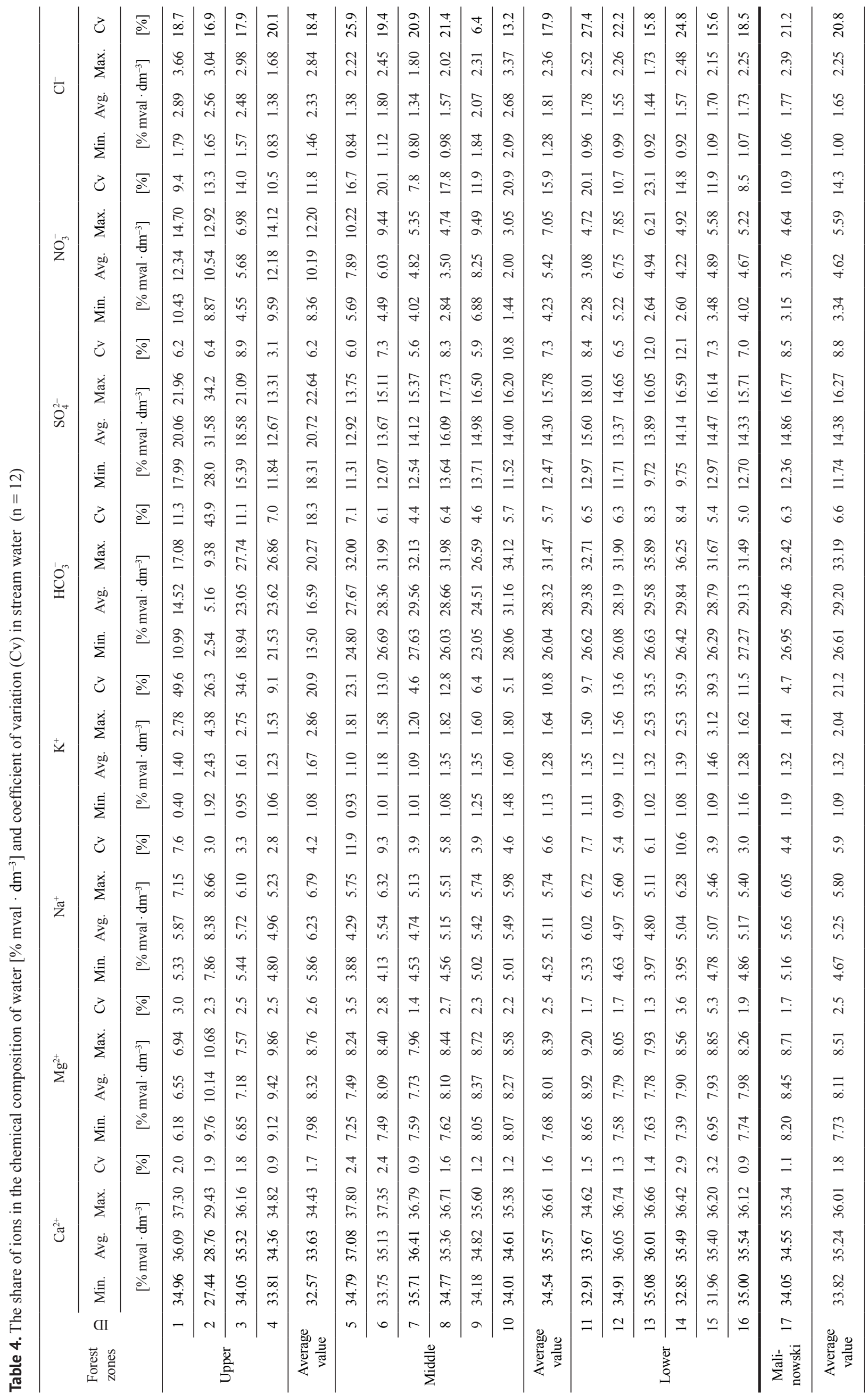


Kosmowska, A. (2019). Impact of deforestation on changes of ion share in chemical composition of waters of the Malinowski stream along longitudinal... Acta Sci. Pol., Formatio Circumiectus, 18 (3), 97-112. DOI: http://dx.doi.org/10.15576/ASP.FC/2019.18.3.97

Table 5. Hydrochemical types of water in the Malinowski stream catchment

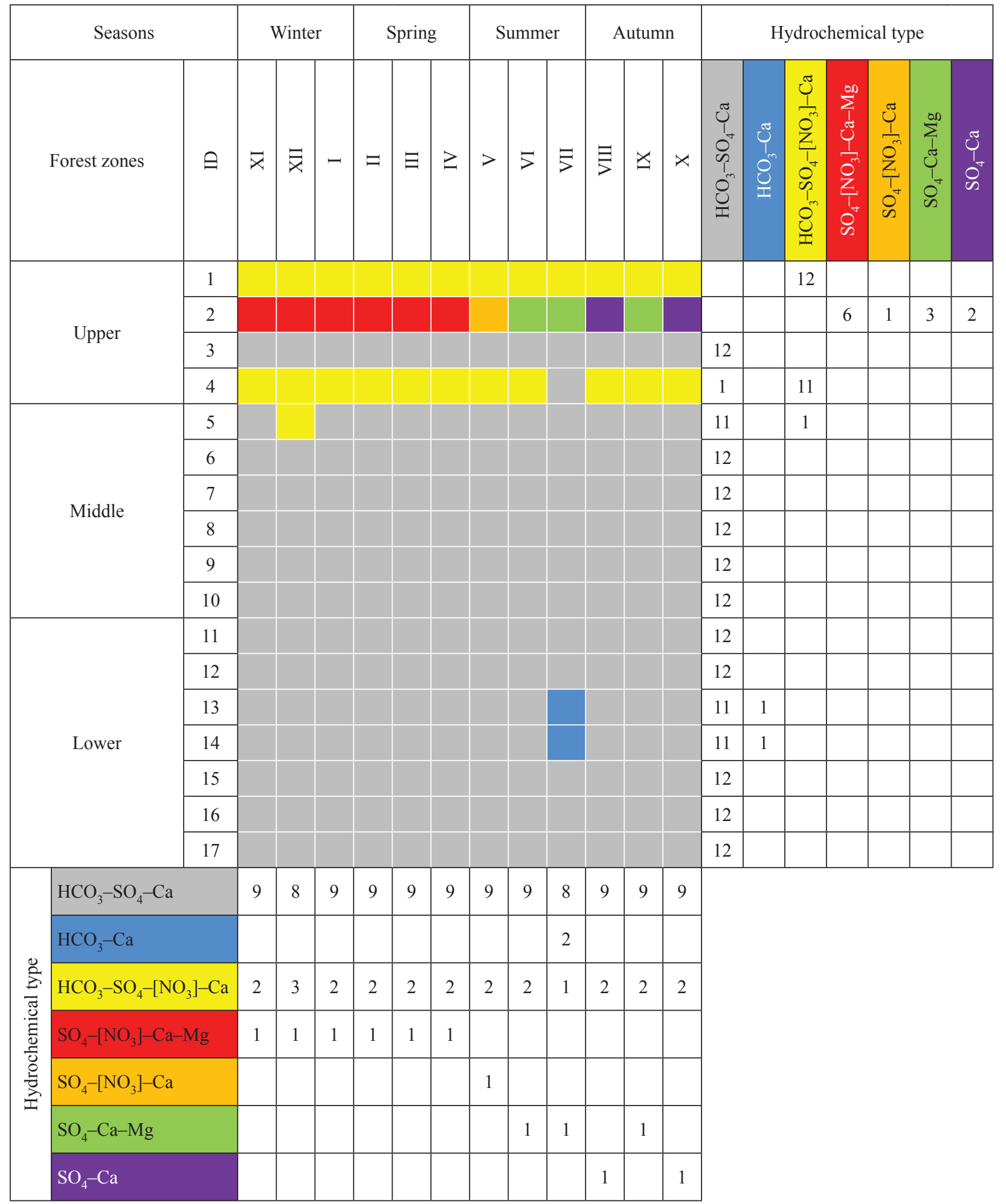


I

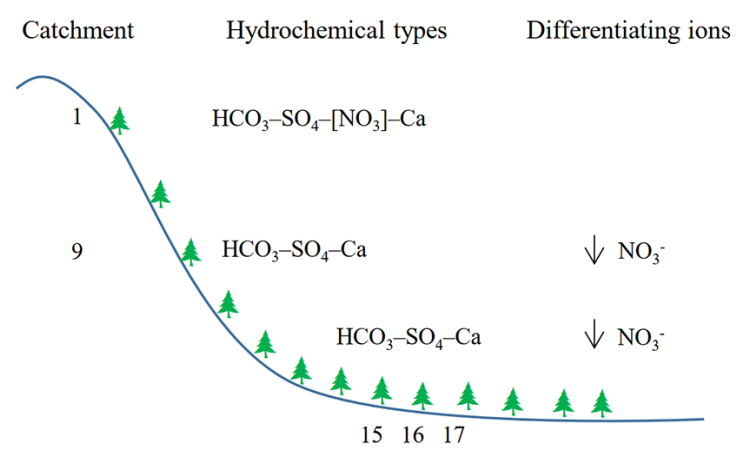

III

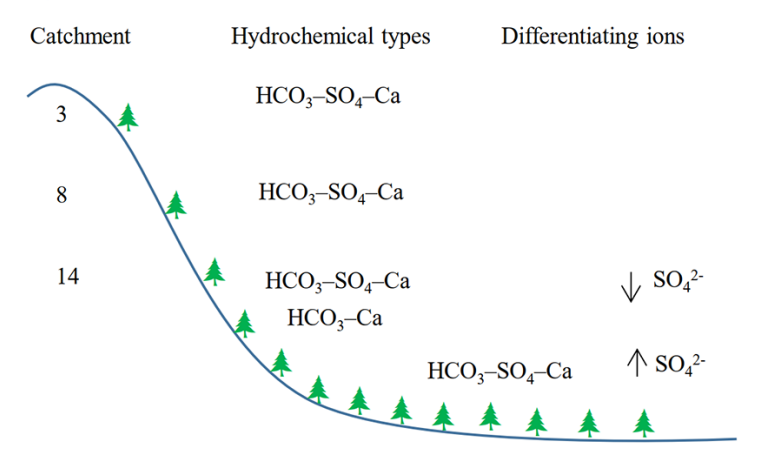

$15 \quad 16 \quad 17$

$\mathrm{V}$

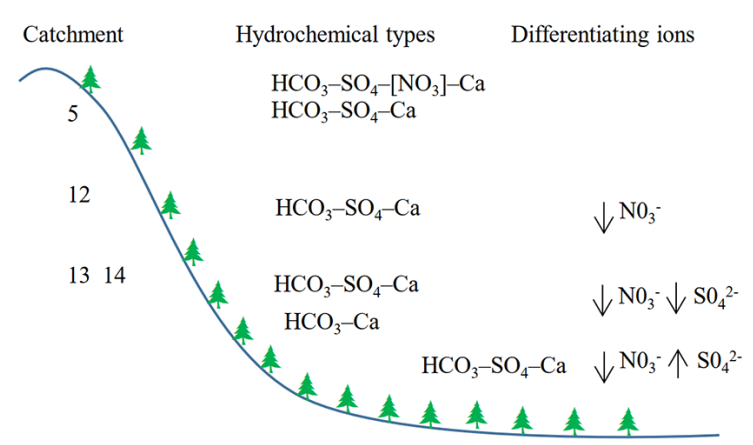

$\begin{array}{llll}15 & 16 & 17\end{array}$
II

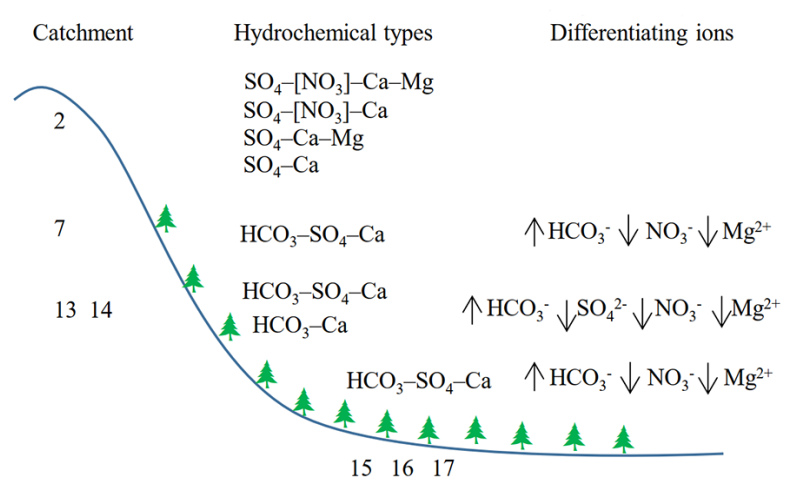

IV

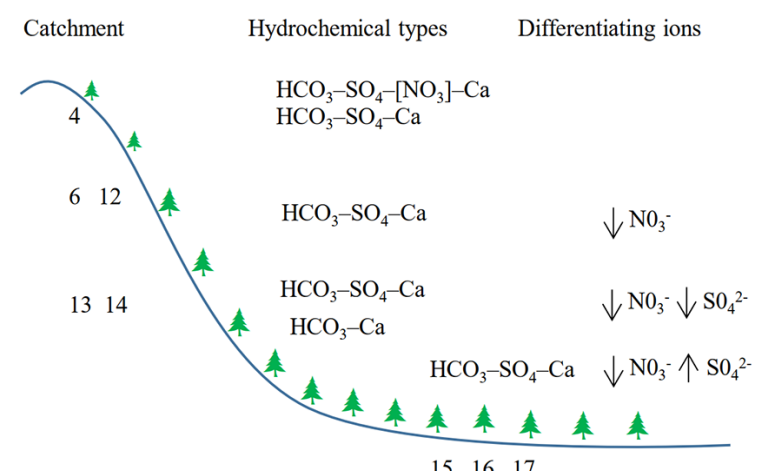

VI

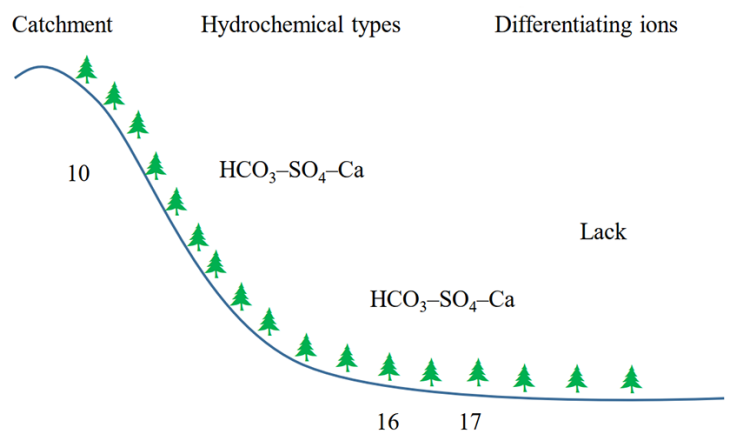

Fig. 2. Longitudinal hydrochemical profiles (I, II, III, IV, V, VI) in the Malinowski stream catchment (1-17 numbers of sub-catchments) 

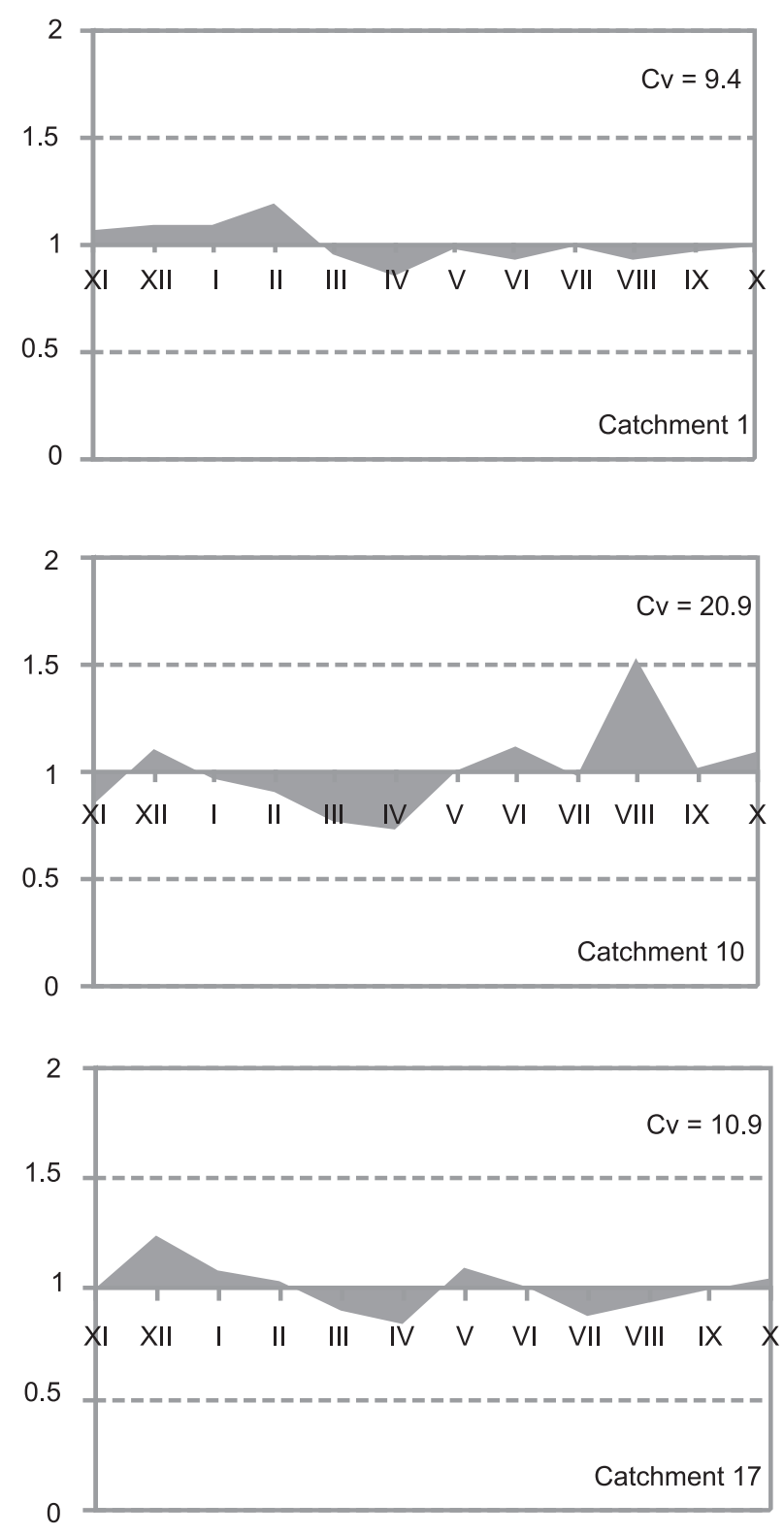

Fig. 3. The course of $\mathrm{NO}_{3}^{-}$regime $\left[\% \mathrm{mval} \cdot \mathrm{dm}^{-3}\right]$ in catchments: $1,10,17$

stand in the Malinowski stream catchment continuously breaks down. It is worth noticing that in deforested catchments, the variability of $\mathrm{NO}_{3}^{-}$in a year is higher $(\mathrm{Cv}=13.3 \%$; catchment no. 2$)$ than in forested catchments $(\mathrm{Cv}=9.4 \%$; catchment no. 1$)$ (see: Table 4). Deforested catchments are characterised mostly by moderate type, while forested ones: moderate and equalised. The most significant changes occur in catchments in which degradation of the forest stand (3, 9,10 ) or its reconstruction (no. 4 - covered by young forest) can be observed.

\section{SUMMARY AND DISCUSSION}

The consequence of deforestation of the slopes in the Silesian Beskid range is a change of the sequence of anions in the chemical composition of water, which is reflected in the hydrochemical types of waters, which are their synthetic image. Share of $\mathrm{SO}_{4}^{2-}$ ions in the chemical composition of water in a stream that drains a catchment that is almost totally deforested (no. 2) was so significant that it was in the first place in this water's hydrochemical type: $\mathrm{SO}_{4}-\left[\mathrm{NO}_{3}\right]-\mathrm{Ca}-\mathrm{Mg}$, $\mathrm{SO}_{4}-\mathrm{Ca}-\mathrm{Mg}, \mathrm{SO}_{4}-\mathrm{Ca}$, and $\mathrm{SO}_{4}-\left[\mathrm{NO}_{3}\right]-\mathrm{Ca}$. Meanwhile, the concentration of $\mathrm{HCO}_{3}^{-}$ions was so low that their share in the chemical composition of water was minimal. Analogous hydrochemical environments in which $\mathrm{SO}_{4}^{2-}$ dominated over $\mathrm{HCO}_{3}^{-}$were described by Michalik (2008) and Michalik et al. (2012) in waters draining quartzite sandstones in the Świętokrzyskie Mountains, and by Kosmowska et al. (2015) and (2018) in the Malinowski stream catchment in the Silesian Beskid range. In the above catchments, the occurrence of $\mathrm{SO}_{4}^{2-}$ in the first place in the hydrochemical type of water is extremely rare for natural waters, especially since the Godula sandstones, that are the geological base of the above catchments, cannot be their source and the origin of $\mathrm{SO}_{4}^{2-}$ must be anthropogenic. In the Tatras, Wolanin et al. (2017) described an unusual chemical composition of a spring, that was dominated by $\mathrm{SO}_{4}^{2-}\left(28.12 \% \mathrm{mval} \cdot \mathrm{dm}^{-3}\right)$ but it was probably genetically connected to gypsum or anhydrite rocks. A significant, and sometimes dominant, share of $\mathrm{SO}_{4}^{2-}$ in the chemical composition of water is associated with atmospheric supply of pollutants in the second half of the 20th century. It resulted in $\mathrm{SO}_{4}^{2-}$ accumulation in the residual soil, and now they are leached from the soil, which was discussed by Jasik and Małek (2013), Kosmowska et al. (2016) and (2018). In the waters draining the lower zone of the Skrzyczne massif and at the closing profile of the Malinowski stream catchment in Lipowa, a sequence of anions can be observed in the chemical composition of water that is typical for waters draining sedimentary rocks in the temperate climate, which is dominated by 
$\mathrm{HCO}_{3}^{-}$, with a smaller share of $\mathrm{SO}_{4}^{2-}, \mathrm{Cl}^{-}$and $\mathrm{NO}_{3}^{-}$. It can be observed in the hydrochemical type of water in which $\mathrm{HCO}_{3}^{-}$are in the first place: $\mathrm{HCO}_{3}-\mathrm{SO}_{4}-\mathrm{Ca}$. This kind of ion sequence, in which $\mathrm{HCO}_{3}^{-}$dominate and are in the first place, was obtained by Drużkowski and Szczepanowicz (1988) in a small catchment called Wierzbanówka in the Carpathian Foothills, Maultz (1972) in big catchments of the upper Wisła (Soła, Skawa), Welc (1985) in the catchment of the Bystrzanka stream, Żelazny (1995) and (2005) in catchments in the Wiśnicz Foothills, Siwek (2012) in small catchments at Carpatian Foothills (catchments of Stara Rzeka, Kubaleniec and Leśny Potok), Żelazny et al. (2017a) and (2017b) in the Kościeliski stream catchment in the Tatras. Also, research conducted in the Kościeliska valley in the Western Tatras confirm it (Żelazny et al., 2013; Kosmowska et al., 2018), as well as several years of observations of 23 streams in the Polish Tatras where Żelazny (2012) showed that $\mathrm{HCO}_{3}^{-}$dominates among anions in the chemical composition of water regardless of hydrometeorological and lithological conditions. It is worth mentioning that in the Tatra catchments the mineralisation of water was strongly differentiated depending on the lithological structure. In the waters of streams draining catchments built up low-soluble granites, mineralisation was very low (avg. $=17.70 \mathrm{mg} \cdot \mathrm{dm}^{-3}$ in the Roztoka catchment), while in catchments built up sedimentary rocks it was much higher (avg. $=301.45 \mathrm{mg} \cdot \mathrm{dm}^{-3}$ in the Wielkie Koryciska catchment) (Żelazny, 2012).

Multidimensional PCA analysis carried out for waters that drain the Malinowski stream catchment did not show the expected seasonal variability of biogenes concentration, e.g. $\mathrm{NO}_{3}^{-}$, i.e. higher in winter, and lower in summer (Kosmowska, 2016). However, the analysis of seasonal variability in the course of $\mathrm{NO}_{3}^{-}$ concentration in waters from individual sub-catchments $\left(\% \mathrm{mval} \cdot \mathrm{dm}^{-3}\right)$ showed typical variability. It is worth noting that among these catchments, also an unusual phenomenon was observed - in summer there is a higher concentration of $\mathrm{NO}_{3}^{-}$than in winter (catchments no. 3, 9, 10). This should be explained by the intensive degradation of the forest stand in these catchments. This applies to catchments heavily transformed due to anthropopressure. According to Vitousek and Reiners (1975), Murdoch and Stoddard (1992), Swank and Vose (1997) this indicates a progressive degradation of the damaged forest stand, which behaves similarly to an aging forest stand and with time loses the ability to actively absorb $\mathrm{NO}_{3}^{-}$in the growing season. Vitousek and Reiners (1975) showed a multiple difference between $\mathrm{NO}_{3}^{-}$concentration in streams draining successional forest catchments (about Avg. $=5 \mu \mathrm{EQ} \cdot \mathrm{dm}^{-3}{ }_{\text {July } 1973}$ ) and oldeged forest catchments (about Arg. $=55 \mu \mathrm{EQ} \cdot \mathrm{dm}^{-3}{ }_{\text {July } 1973}$ ). For most catchments located in the middle and lower zones of the Skrzyczne massif, a typical course of $\mathrm{NO}_{3}^{-}$concentration was observed - higher concentration in winter, and lower in summer. Similar results $-\mathrm{NO}_{3}^{-}$concentration increase in non-growing period, and decrease in growing period - were obtained in the Tatras by Żelazny (2012), Wolanin (2013), Gromadzka et al. (2015), Sajdak et al. (2018), in the Babia Góra National Park by Malata (2015), in the Gorce range by Jasik et al. (2017), in the Silesian Beskid and the Żywiec Beskid by Astel et al. (2008), as well as in small agricultural catchments in the Lower Silesia by Pulikowski et al. (2005) and (2011). Similar seasonal variation in $\mathrm{NO}_{3}^{-}$was observed in a small urbanised catchment in England by Worrall and Burt (1998) and in the UK by Jarvie et al. (2010).

Analysing the changes in the hydrochemical types of waters along the longitudinal profiles in the Malinowski stream catchment, attention should be paid to the differences expressed in hydrochemical types in the chemical composition of the water draining the deforested upper zone of the Skrzyczne massif in comparison to the lower zone. As the catchment area increases, the share of $\mathrm{NO}_{3}^{-}$in the chemical composition of water decreases, and the share of $\mathrm{HCO}_{3}^{-}$increases. Unique hydrochemical types of waters that drain the upper zone of the Skrzyczne massif (catchment no. 2) $-\mathrm{SO}_{4}-\left[\mathrm{NO}_{3}\right]-\mathrm{Ca}-\mathrm{Mg}, \mathrm{SO}_{4}-\mathrm{Ca}-\mathrm{Mg}, \mathrm{SO}_{4}-$ $\mathrm{Ca}$, and $\mathrm{SO}_{4}-\left[\mathrm{NO}_{3}\right]-\mathrm{Ca}-$ are the result of the forest stand degradation. Also, the methodological aspect related to the analysis of longitudinal hydrochemical profiles is important. The analysis of the ion share in the chemical composition of water that was carried out in the longitudinal hydrochemical profiles allows the identification of the hydrochemical effects of the degradation of the forest stand in the mountain catchment. It is worth noting that if the tests were carried out exclusively in the closing profile of the Malinowski stream catchment in Lipowa, then this catchment 
would be a typical Carpathian catchment in terms of hydrochemistry, where $\mathrm{HCO}_{3}^{-}$is in the first place in the anionic part of the chemical composition. This would "mask" the impact of anthropogenic influence on the hydrochemical functioning of the catchment.

\section{ACKNOWLEDGEMENTS}

The research was conducted within the 2011/01/B/ NZ9/04615 grant by the National Science Centre - ,The impact of deforestation caused by ecological disaster on the spatial variation and changes in the chemistry of source and surface waters in the Silesian Beskid.”

\section{REFERENCES}

Alexandrowicz, S.W. (1999). Budowa geologiczna. In: L. Starkel (red.). Geografia Polski. Środowisko przyrodnicze. Warszawa: PWN, 221-242.

Astel, A., Małek, S., Krakowian, K. (2008). Sustainable afforestation as a tool of spring water sources protection in the mountain ecosystem. Pol. J. Environ. Stud., 17(3a), 22-27.

Balon, J., Jodłowski, M. (2014). Regionalizacja fizycznogeograficzna Karpat Zachodnich - studium metodologiczne. In: W. Ziaja, M. Jodłowski (red.). Struktura środowiska przyrodniczego a fizjonomia krajobrazu. Kraków: IGiGP UJ, 85-105.

Barszcz, J. Małek, S. (2015). Przyczyny zamierania świerczyn. In: S. Małek (ed.), Ekologiczne i hodowlane uwarunkowania przebudowy drzewostanów świerkowych w Beskidzie Śląskim i Beskidzie Żywieckim. Kraków: Wyd. Uniwersytetu Rolniczego w Krakowie.

Borg, H., Sundbom, M. (2014). Long-term trends of water chemistry in mountain streams in Sweden - slow recovery from acidification. Biogeosciences 11, 173-184.

Bytnerowicz, A., Godzik, B., Frączek, W., Grodzińska, K., Krywult, M., Badea, O., Barančok, P., Blum, O., Černy, M., Godzik, S., Mankovska, B., Manning, W., Moravčik, P., Musselman, R., Oszlányi, J., Postelnicu, D., Szdzuj, J., Varšavova, M., Zota, M. (2002). Distribution of ozone and other air pollutants in forests of the Carpathian Mountains in central Europe. Environ. Pollut., 116(1), 3-25.

Capecki, Z. (1994). Rejony zdrowotności lasów zachodniej części Karpat. Prace Inst. Bad. Leśn., A 781, 83-191.

Chełmicki, W. (2012). Woda. Zasoby, degradacja, ochrona. Warszawa: PWN.

Czop, M., Motyka, J., Rajchel, L. (2008). Zagrożenia środowiska wód mineralnych rejonu Piwnicznej przez tu- rystykę narciarską. In: M. J. Kotarba (red.), Przemiany środowiska naturalnego a rozwój zrównoważony. Kraków: Wyd. TBPŚ „Geosfera”, 175-188.

Drużkowski, M., Szczepanowicz, B. (1988). Migracja pierwiastków w wodach powierzchniowych i opadach atmosferycznych na obszarze małej zlewni Pogórza Karpackiego. Folia Geographica, seria GeographicaPhisyca 20, 101-120.

Durło, G. (2012). Wpływ obserwowanych i prognozowanych warunków klimatycznych i obserwowanych na stabilność drzewostanów górskich w Beskidzie Śląskim. Kraków: Wyd. Uniwersytetu Rolniczego w Krakowie.

Geologiczna Mapa Polski 1:50000. (1966a). Region Karpat i Przedgórza. Arkusz M34-87 A: Milówka. Instytut Geologiczny Oddział Karpacki, Wydawnictwa Geologiczne.

Geologiczna Mapa Polski 1:50000. (1966b). Region Karpat i Przedgórza. Arkusz M34-86 B: Wisła. Instytut Geologiczny Oddział Karpacki, Wydawnictwa Geologiczne.

Gromadzka, M., Wolanin, A., Żelazny, M., Pęksa, Ł. (2015). Physical and chemical properties of the Goryczkowe and Bystrej Górne vaucluse springs in the Tatra Mountains. Hydrology Research, 46(6), 954-968.

Hydrologiczny rocznik wód powierzchniowych. (1974-1983). Instytut Meteorologii i Gospodarki Wodnej, Wyd. Komunikacji i Łączności.

Jasik, M., Małek, S. (2013). Quality assessment of spring water from the area of the Łysogóry Mts. In Świętokrzyski National Park in 2010. Folia For. Pol., Ser. A, Leśn., 55(1), 27-32.

Jasik, M., Małek, S., Żelazny, M. (2017). Effect of water stage and tree stand composition on spatiotemporal differentiation of spring water chemistry draining Carpathian flysch slopes (Gorce Mts). Science of the Total Environment, 599-600, 1630-1637.

Jarvie, H.P., Withers, P. J.A., Bowes, M.J., Palmer-Felgate, E.J., Harper, D.M., Wasiak, K., Wasiak, P., Hodgkinson, R.A., Bates, A., Stoate, C., Neal, M., Wickham, H.D., Harman, S.A., Armstrong, L.K. (2010). Streamwater phosphorus and nitrogen across a gradient in rural-agricultural land use intensity. Agriculture, Ecosystems and Environment 135, 238-252.

Kosmowska, A., Żelazny, M., Małek, S., Siwek, J. P. (2015). Wpływ wylesień na krótkoterminowe zmiany składu chemicznego wody w zlewni Potoku Malinowskiego (Beskid Śląski). Sylwan, 159(9), 778-790.

Kosmowska, A., Żelazny, M., Małek, S., Siwek, J.P., Jelonkiewicz, Ł. (2016). Effect of deforestation on stream water chemistry in the Skrzyczne massif (the Beskid 
Śląski Mountains in the southern Poland). Science of the Total Environment, 568, 1044-1053.

Kosmowska, A., Żelazny, M., Małek, S., Stańczyk, T. (2018). Impact of deforestation on water chemistry in the Western Tatras and Beskid Śląski range in the Polish Carpathians. Acta Sci. Pol. Formatio Circumiectus, 18(3), 89-99.

Macioszczyk, A. (1987). Hydrogeochemia. Warszawa: Wydawnictwa Geologiczne.

Malata, M. (2015). Sezonowa zmienność fizyko-chemiczna źródeł Babiogórskiego Parku Narodowego. Prz. Nauk. Inż. Kszt. Środ., 67, 26-39.

Małek, S. (2010). Nutrient fluxes in planted Norway spruce stands of different age in Southern Poland. Water Air Soil Pollut., 209(1), 45-59.

Małek, S. (2015). Obieg biogeochemiczny w małych zlewniach leśnych $\mathrm{z}$ dużym udziałem świerka. In: S. Małek (ed.), Ekologiczne i hodowlane uwarunkowania przebudowy drzewostanów świerkowych w Beskidzie Śląskim i Beskidzie Żywieckim. Kraków: Wyd. Uniwersytetu Rolniczego w Krakowie.

Małek, S., Gawęda, T. (2004). The characteristic of surface water of Potok Dupniański and Olza drainage area in Beskid Śląski. Zeszyty Naukowe, Inżynieria Środowiska 131(12), 257-264.

Małek, S., Gawęda, T. (2006a). Charakterystyka chemiczna wód powierzchniowych zlewni Potok Dupniański w Beskidzie Śląskim. Sylwan, 150(2), 29-36.

Małek, S., Gawęda, T. (2006b). Charakterystyka chemiczna źródeł Potoku Dupniańskiego w Beskidzie Śląskim. Sylwan, 150(3), 39-46.

Małek, S., Krakowian, K. (2012). The effect of deforestation on spring water chemistry on Skrzyczne (Silesian Beskid Mountains, Poland). J. For. Sci., 58(7), 308-313.

Małek S., Barszcz, J., Kędziora, B. (2012b). Factors influencing silvicultural value of cultures of silver fir Abies alba Mill. at higher altitudes in the Beskid Śląski and Beskid Żywiecki Mountains. Folia Forestalia Polonica series A 54 (3), 145-152.

Małek, S., Barszcz, J., Majsterkiewicz, K. (2012a). Changes in the threat of spruce stand disintegration in the Beskid Śląski and Żywiecki Mts in the years 2007-2010. Journal of Forest Science 58 (12), 519-529.

Małek, S., Martinson, L., Sverdrup, H. (2005). Modeling future soil chemistry at a highly polluted forest site at Istebna in Southern Poland using the "SAFE" model. Environmental Pollution 137(3), 568-573.

Maultz, S. (1972). Chemizm wód dopływów Górnej Wisły. Folia Geographica, Series Geographica-Physica, 6, 5-101.
Michalik, A. (2008). The use of chemical and cluster analysis for studying the spring water. Quality in the Świętokrzyski National Park, South-Central Poland. Polish Journal of Environmental Studies, 17(3), 357-362.

Michalik, A., Migaszewski, Z. M. (2012). Stable sulfur and oxygen isotope ratios of the Świętokrzyski National Park spring waters generated by natural and anthropogenic factors (south-central Poland). Applied Geochemistry, 27(6), 1123-1132.

Moldan, B., Schnoor, J.L. (1992). Czechoslovakia: examining a critically ill environment. Environ. Sci. Technol., 26(1), 14-21.

Murdoch, P.S., Stoddard, J.L. (1992). The role of nitrate in the acidification of streams in the Catskill Mountains of New York. Water Resour. Res., 28(10), 2707-2720.

PN-89/C-04638/02. Bilans jonowy wody. Sposób obliczenia bilansu jonowego wody. PKNMiJ.

Oszczypko, N. (1995). The Miocene subsidence history of the Carpathian Foredeep in Poland. Special Publications of the Geological Society of Greece 4(1), 372-379.

Ozga-Zielińska, M., Brzeziński, J. (1994). Hydrologia stosowana. Warszawa: Wydawnictwo Naukowe PWN.

Pazdro Z., Kozerski B. (1990). Hydrogeologia ogólna. Warszawa: Wydawnictwa Geologiczne.

Pulikowski, K., Paluch, J., Paruch A., Kostrzewa, S. (2005). Okres pojawiania się maksymalnych stężeń azotanów w wodach powierzchniowych. Zesz. Probl. Post. Nauk Rol., Warszawa 505, 339-345.

Pulikowski, K., Czyżyk, F., Pawęska, K., Strzelczyk, M. (2011). Sezonowe zmiany wielkości ładunku azotu odpływającego z mikrozlewni użytkowanych rolniczo. Infrastruktura i ekologia terenów wiejskich, 10, PAN, Kraków, 161-171.

Ratajczak, T., Witczak, S. (1983). Mineralogia i hydrogeochemia żelaza w kolmatacji filtrów studziennych ujmujących wody czwartorzędowe. Zesz. Nauk. AGH, Geologia 29. 229 s. Cyt. za: Witczak, S., Kania, J., Kmiecik, E. (2013). Katalog wybranych fizycznych i chemicznych wskaźników zanieczyszczeń wód podziemnych i metod ich oznaczania. Biblioteka Monitoringu Środowiska, Warszawa.

Sajdak, M., Siwek, J., Bojarczuk, A., Żelazny, M. (2018). Hydrological and chemical water regime in the catchments of Bystra and Sucha Woda in the Tatra National Park. Acta Sci. Pol. Formatio Circumiectus, 17(3), 161-173.

Siwek, J. P. (2012). Zmienność składu chemicznego wód w małych zlewniach na progu Pogórza Karpackiego. Kraków: Instytut Geografii i Gospodarki Przestrzennej UJ.

Swank, W. T., Vose, J. M. (1997). Long-term nitrogen dynamics of Coweeta forested watersheds in the southeastern 
United States of America. Global Biogeochemical Cycles, 11(4), 657-671.

Vitousek, P. M., Reiners, W. A. (1975). Ecosystem succession and nutrient retention: a hypothesis. BioScience, 25(6), 376-381.

Welc, A. (1985). Zmienność denudacji chemicznej w Karpatach fliszowych (na przykładzie zlewni potoku Bystrzanka). Dokumentacja Geograficzna 5.

Wolanin, A. (2013). Właściwości fizykochemiczne wody potoków tatrzańskich w okresie kwiecień-listopad 2011 roku. Prace Geograficzne. Kraków: Instytut Geografii i Gospodarki Przestrzennej UJ, 133.

Wolanin, A., Chmiel, S., Żelazny, M., Jelonkiewicz, Ł., Janusz, J., Hałas, S., Trembaczowski, A. (2017). Anomalia hydrogeochemiczna w Tatrach: źródło z wodami siarczanowymi. Przegląd Geologiczny, 65(11/1), 1025-1028.

Worrall, F., Burt, T. P. (1998). Decomposition of river water nitrate time series - comparing the agricultural and urban signs. Science of the Total Environment, 210-211, $153-162$

Żelazny, M. (1995). Chemizm wód powierzchniowych i podziemnych w zlewni Starej Rzeki (Pogórze Wielickie). In: L. Kaszowski (ed.). Struktura i funkcjonowanie środowiska przyrodniczego Progu Karpat: wyniki badań Stacji Naukowej Instytutu Geografii Uniwersytetu Jagiellońskiego w Łazach. Zeszyty Naukowe Uni- wersytetu Jagiellońskiego, Prace Geograficzne, 100, 73-83.

Żelazny, M. (ed.). (2005). Dynamika związków biogennych w wodach opadowych, powierzchniowych i podziemnych w zlewniach o różnym użytkowaniu na Pogórzu Wiśnickim. Kraków: Instytut Geografii i Gospodarki Przestrzennej Uniwersytetu Jagiellońskiego.

Żelazny, M., (2012). Czasowo-przestrzenna zmienność cech fizykochemicznych wód Tatrzańskiego Parku Narodowego. Kraków: Instytut Geografii i Gospodarki Przestrzennej UJ.

Żelazny, M., Kosmowska, A., Stańczyk, T., Mickiewicz, M. (2017 a). Effect of deforestation on water chemistry in the Kościeliska Valley in the Western Tatras in southern Poland, Annals of Warsaw University of Life SciencesSGGW, Land Reclamation 49(3), 223-235.

Żelazny, M., Siwek, J.P., Fidelus, J., Stańczyk, T., Siwek, J., Rutkowska, A., Kruk, P., Wolanin, A., Jelonkiewicz Ł. (2017 b). Wpływ wiatrołomu i degradacji drzewostanu na zróżnicowanie chemizmu wód w zlewni Potoku Kościeliskiego w obszarze Tatrzańskiego Parku Narodowego. Sylwan, 161(1), 27-33.

Żelazny, M., Wolanin, A., Płaczkowska, E. (2013). Hypsometric factors for differences in chemical composition of Tatra National Park spring waters. Polish Journal of Environmental Studies, 22(1), 289-299.

\section{WPŁYW WYLESIENIA NA ZMIANY UDZIAŁU JONÓW W SKŁADZIE CHEMICZNYM WÓD MALINOWSKIEGO POTOKU WZDŁUŻ PODŁUŻNYCH PROFILI HYDROCHEMICZNYCH}

\section{ABSTRAKT}

\section{Cel pracy}

Celem badań było określenie zmian udziału jonów w składzie chemicznym wody wraz z przyrostem powierzchni zlewni wzdłuż podłużnych profili hydrochemicznych na obszarze dotkniętym klęską ekologiczną.

\section{Materiat i metody}

Badania prowadzono w zlewni Malinowskiego Potoku w Masywie Skrzyczne w Beskidzie Śląskim, w latach 2013-2014. Zlewnię Malinowskiego Potoku podzielono na mniejsze zlewnie cząstkowe: zależne i niezależne oraz wyodrębniono 6 profili podłużnych wzdłuż zlewni wraz z przyrostem powierzchni zlewni. W terenie pobierano co miesiąc próbki wody w zlewniach o różnym stopniu wylesienia oraz mierzono cechy fizyczno-chemiczne wody $\left(\mathrm{pH}, \mathrm{EC}_{25^{\circ} \mathrm{C}}, \mathrm{Tw}\right)$. W laboratorium metodą chromatografii jonowej (DIONEX 2000) oznaczono skład chemiczny wód w zakresie 14 jonów $\left(\mathrm{Ca}^{2+}, \mathrm{Mg}^{2+}, \mathrm{Na}^{+}, \mathrm{K}^{+}, \mathrm{NH}_{4}^{+}, \mathrm{Li}^{+}, \mathrm{HCO}_{3}^{-}, \mathrm{SO}_{4}^{2-}, \mathrm{Cl}^{-}\right.$, $\left.\mathrm{NO}_{2}^{-}, \mathrm{NO}_{3}^{-}, \mathrm{PO}_{4}^{3-}, \mathrm{Br}^{-}, \mathrm{F}^{-}\right)$.

\section{Wyniki i wnioski}

Przeprowadzone badania wykazały wpływ wylesienia na udział jonów w składzie chemicznym wody. W zlewniach wylesionych zaobserwowano wzrost udziału $\mathrm{SO}_{4}^{2-}$ i spadek $\mathrm{HCO}_{3}^{-}$. Udział $\mathrm{SO}_{4}^{2-}$ w wodach odwadniających zlewnię wylesioną był tak duży, że pojawił się na pierwszym miejscu w typie hydrochemicznym tych wód, zaś $\mathrm{HCO}_{3}^{-}$miały tak niewielkie stężenie, że ich udział był znikomy. Analizując zmiany typów 
hydrochemicznych wzdłuż profili podłużnych, zauważono odmienność składu chemicznego wód odwadniających górną, wylesioną strefę, w porównaniu do dolnej. Wraz z przyrostem powierzchni zlewni, następuje spadek znaczenia $\mathrm{NO}_{3}^{-}$i wzrost znaczenia $\mathrm{HCO}_{3}^{-}$. Gdyby badania prowadzono jedynie w profilu zamykającym zlewnią Malinowskiego Potoku, wówczas zlewnia ta byłaby typową zlewnią karpacką pod względem hydrochemicznym, gdzie na pierwszym miejscu w składzie chemicznym wody występują wodorowęglany. Analiza składu chemicznego wód przeprowadzona w podłużnych profilach pozwala zidentyfikować hydrochemiczne skutki rozpadu drzewostanu w zlewni górskiej.

Słowa kluczowe: chemizm wód, wylesienie, kwaśne opady, stężenie $\mathrm{NO}_{3}^{-}$i $\mathrm{SO}_{4}^{2-}$ 